\title{
The Case for Interdisciplinary Crisis Studies ${ }^{1}$
}

Annika Bergman-Rosamond ${ }^{1}$, Thomas Gammeltoft-Hansen², Mo Hamza ${ }^{3}$, Jeff Hearn ${ }^{4}$, Vasna Ramasar, ${ }^{5}$ and Helle Rydstrom ${ }^{6}$

Accepted for Global Discourse: An Interdisciplinary Journal of Current Affairs and Applied Contemporary Thought

1 Department of Political Science, Lund University, Sweden.

Faculty of Law, University of Copenhagen, Denmark.

3 Division of Risk Management and Societal Safety, Lund University, Sweden.

4 Management and Organisation, Hanken School of Economics, Finland; Gender Studies, Örebro University, Sweden; Sociology, University of Huddersfield, UK; Institute for Social and Health Studies, University of South Africa.

5 Division of Human Ecology and Lund University Centre for Sustainability Studies, Lund University, Sweden.

6 Department of Gender Studies, Lund University, Sweden. 


\section{Introduction}

Alarming reports on crises are appearing and being published on a daily basis in different expressions from climate change, to people's movement and displacement, to armed conflict. Claims to crisis may involve tangible displays of desperate refugees, civilian casualties or persisting, if not, permanent poverty. Moreover, crisis relates to more abstract concepts such as failing democracy, instability in the liberal world order or national and global economic inequality. Crisis, in a sense, seemingly weaves the contemporary world together (Latour 1993), and this trend is reinforced by the frequent occurrence of mediatized or media-tuned global crisis narratives, many of which are currently shaped by populist apocalyptic ideology (Judis 2016). At the same time, crisis refers to social forces that can disrupt life and frame realities in ways, which go beyond prevalent discursive narratives (Jaques 2009; Smith and Vivekananda 2009). Crisis can also serve as a turning point and an opportunity for transformational change in a system (e.g. Polanyi 1944; Walby 2015). In particular, we outline an interdisciplinary approach to crisis as both concept and event, and thus to crisis studies, that moves away from some tendencies to see crisis as ahistorical, but rather emphasises uncertainty and contingency.

As we highlight, the various kinds of crises with which contemporary societies struggle cannot be captured within the conceptual framework of a single discipline (e.g. Griffin 2015). 'Siloed' disciplinary approaches have proven to be incapable of drawing the lines between, not just the varied issues at stake, but also the complex map of dots and the intersections of environmental, socio-economic, political, and medical factors that together define a given crisis (Godfrey and Torres 2016). Supposedly distinctive spheres are intertwined, as indicated by the Anthropocene, which emerges as a consequence of human interaction with ecosystems (Crutzen 2006; Kinnvall and Rydstrom 2019). The study of crisis ultimately concerns the entanglement of various science traditions and in this article we, therefore, suggest a multiand interdisciplinary approach to bridge between traditionally separated realms.

Engaging disciplines means a creative testing of combinations and consideration of scientific problems and questions they generate (Dewey 1997; Repko et al. 2014). Such an inventory approach engages directly with a growing concern amongst academics, agencies and decision makers about how to develop more adequate analytical tools for understanding crisis as a multidimensional phenomenon (Hamza 2015). In this, we aspire to a trans-disciplinary 
approach, whilst being keenly conscious of the practical and onto-epistemological challenges that poses, in bringing together diverse frames of references, conceptualisations and lexicons.

This article is the result of a collective multidisciplinary research group, with authors listed alphabetically, working together long-term, and as such represent the first in a series of collective writings on crisis and crises. In this article, we examine a number of approaches to crisis. In so doing, we ask how crisis can be conceptualized, and, what the analytical potentials of a distinct crisis perspective might be? Our ambition is to present a case for the development of Interdisciplinary Crisis Studies as a field of scholarly enquiry, which allows for new perspectives on data collection and analysis. More specifically, we make a case for an interdisciplinary approach that brings together new knowledge and multiple insights.

\section{Some basic distinctions: What is crisis?}

There are several ways of approaching conceptualizations of crisis. One first step could be to address the origins of the word and its etymological origins. According to the Etymology Dictionary, the root of crisis is krinein, which means to "separate, select, decide, judge" and, moreover, "judgement, result of a trial, selection" (i.e. from krei to "discriminate and distinguish"). ${ }^{2}$ Crisis is in turn a Latinized form of the Greek word krisis, which in Ancient Greece indicates the decisive turning point when a person is suffering from illness; i.e. "the change which indicates recovery or death". Krisis or crisis in its medical form thus indicates a "vitally important or decisive state of things" defined as a "point at which change must come, for better or worse".

Change then indicates change for better or worse, as also highlighted by the Merriam-Webster Thesaurus, ${ }^{3}$ which identifies a range of temporal and emotional features of crisis including:

\subsection{A turning point.}

1.2. An attack of pain, distress or disorder.

1.3. An emotionally significant event.

2.1. A decisive moment.

3.1. A crucial state or unstable state of affairs during which a decisive change is impending especially one with the possibility of a highly undesirable outcome. 3.2. A situation that has reached a critical phase. 
Temporally, crisis thus directs us both backwards and forwards, and at times produces a sentiment of existing in a void. The forward-looking dimensions to crisis entail a vision of a forthcoming dystopia or catastrophe, but importantly, can also contain an element of productive power enabling action. In the Ancient Greek usage, crisis is the necessary step before a change takes place. An example here is when a catastrophe or a disaster points to weaknesses in a system following which measures and mechanisms could be put in to avoid or limit the effect of future occurrence. Advances in reducing risks from disasters came out of learning from major events. Both practitioners and scholars make claims to crisis to foreground the need for paradigmatic changes, redemption or revolution or extraordinary measures such as these relating to imprisonment of asylum seekers and refugees (see e.g. Agamben 1998, 2005; Butler 2010; Walby 2015).

Studying crisis is challenging, though, due to the ways in which crisis as a notion, condition and experience refers to and operates at various societal levels. Crisis talk might be used as rhetoric by politicians, policy-makers, activists and others, as an ideological tool and rhetorical move to galvanize a political base (Hearn and Roberts 1976; Hearn 1982; Walby 2015). At the same time, crisis can be experienced as very real framing of life due to socioeconomic and political inequalities and unequal power relations both at the level of the system and lifeworld. A key task is to distinguish between various types of crisis, including: the politically manufactured, for instance, shaped as xenophobia; a crisis of emergency due to an abrupt incident, such as a climate disaster; crisis when living at the margins, for example, on a minimum existence level in the Global North or Global South; or crisis as a matter of being caught in a space of interpersonal violence (Rydstrom 2017, 2019a, 2019b). Crisis is thus a cross-cutting phenomenon which takes multiple directions that, however, might intersect at certain moments in time, and can range across: crisis rhetoric; lifeworld experiences of crisis; crisis as emergency; and structural crisis conditions.

Distinctions can also be made in relation to the form and extent of change a crisis constitutes or could potentially bring. Crisis may be seen as overlapping or even merging with isolated occurrences of disasters, on the one hand, and longer-term and often more gradual declines and degenerations, on the other. Crisis, longer-term degenerative change, and more immediate, sometimes more short-lived disasters can be distinguished partly with regard to their extent (of change and effects) across time, and their extent, scale or scope (of change) across space - local, regional, global, and so on. We return to this theme of scale shortly. 


\section{From disciplinarity, towards interdisciplinarity}

Beyond these initial clarifications, both claims to and conceptual discussions about crisis still remain highly contested. In part, this arises from different disciplinary emphases and traditions. Many disciplinary insights and contributions, emerging from anthropology, political science and international relations, psychology, sociology, economics, development studies, migration studies, global health studies, environmental studies are available for the interrogation of crisis/es. Disciplinary perspectives vary greatly in substance and content, in relation to their ontological and epistemological assumptions, and regarding their analytical development over time. Furthermore, disciplinary traditions vary in the extent to which crisis is seen as endogenous (internally-focused) and/or exogenous (externally-focused).

While the approach we are developing here leans toward large-scale crises, it is important to note scholarship on social psychological or therapeutic crisis are both omnipresent and influential but more personal and individual in their orientation. Indeed, one of the most abundant literatures concerns personal and psychological crisis. While the structure and modelling of personal stresses and crises (e.g. Cohen et al. 2016) may have some similarities with more societal crises, and the latter are also experienced within such wider crises, we concern ourselves primarily with the latter approach.

The question of crisis has also figured prominently in a number of anthropological texts, which have examined crisis conceptually and as a social reality. Notable here are Janet Roitman's book, Anti-Crisis (2014), and Henrik Vigh's (2008) contribution in a special issue on 'Crisis and Chronicity: Anthropological Perspectives on Continuous Conflict and Decline' published in Ethnos, Journal of Anthropology, with the latter including a number of articles and plenty of further elaborations and responses (e.g. Berckmoes 2017; Cabot 2018; Rydstrom 2019a, 2019b, in press; Samimian-Darash and Rotem 2018; Zhukova 2019).

Within sociology, Sylvia Walby's book Crisis (2015) on financial crisis, fiscal policy and gender stands out, while crisis and time are recurrent themes in philosophy (e.g. Kierkegaard 1847; Koselleck [1959] 1988). In political science and economy, Karl Marx (1967/885) identified in Capital (from German Das Kapital vol. 1 and 2) what he saw as the systemic roots of economic crisis while Nancy Fraser (2001) and Jürgen Habermas have identified an underpinning political crisis of democracy in the western context. Research on climate 
catastrophes, movements and wars and the aftermath is very extensive (e.g. Bradshaw 2013; Buckingham and Masson 2017; Enarson and Pease 2016; Gammeltoft-Hansen 2016; Hamza et al. 2010; Kinnvall and Rydstrom 2019; Rydstrom and Kinnvall 2019), and the same holds for feminist research on socio-economic inequalities, crisis and violence (e.g. Hearn 1998; Rydstrom 2017, in press; True 2012, 2013).

A key line of analysis emphasises the fundamental, historical and endemic instability, or what could be defined as crisis-tendencies of society, political economy and social institutions. Endemic instability is highlighted in some critical scholarship, but is also present in some more mainstream analyses. For example, within mainstream historical scholarship, Niall Ferguson (2012) in The Great Degeneration: How Institutions Decay and Economies Die has examined the relatively longer-term societal changes through the degeneration of institutions once considered the "pillars" of Western society: representative government, free market, rule of law, civil society, rather than focusing on specific crises. Taking a more contemporary focus, in The Origins of Political Order and Political Order and Political Decay, Francis Fukuyama $(2011,2014)$ pointed to the fragility of liberal national democracy in the emerging global world order (see Hearn et al. 2019). Working broadly from the disciplines of geography and environmental history, Jared Diamond $(2005,2019)$ has analysed how and why societies collapse, or descend into, or indeed survive, crisis.

The theme of the endemic nature of crisis is usually associated with crisis tendencies under capitalism. Marx and Engels (1848/2010) wrote in The Communist Manifesto that "all that is solid melts into air", as echoed by Marshall Berman in 1982. That capitalism destroys social values has been highlighted by conservative and reactionary commentators, but both Marx and Berman, among many others, saw the radical and liberatory potential of the insight. There have been innumerable studies of capitalist crisis, boom and slumps, the global falling rate of profit, economic "contagion" effects from imperialist centre(s) to peripheries, and shifting of crisis from economic to financial to fiscal to political (for recent commentaries see, for example, Ba 2017; Carchedi and Roberts 2018; Sum and Jessop 2013; Walby 2015). A key question such approaches highlight is to what extent crisis is endemic to capitalism producing policies of austerity that further sustain the endemic features of people's sense of existing in permanent economic hardship. Similar questions can be raised relative to other exploitative social orders, for example, imperialism, colonialism, patriarchy (see Connell 1987; Habermas 1976; Said 1979; Sen 2012; Shiva 2012; Starck and Luyt 2018). 
Long-term decline and degeneration, and the possible endemic nature of some forms of societal crisis are both suggestive of the need for more multidisciplinary or interdisciplinary perspectives on crisis encompassing, for example, anthropology, economics, law, political science and sociology. They are thus relevant in our approach, but they are not determining factors. Rather, and more particularly, we see crisis as more limited by way of the nonproportionate, extensive and large-scale changes and effects following a relatively small event in a narrow time window (Walby 2015); as such, this view of crisis can be local, personal, widespread or even global, overlapping with notions of tipping points and irreversible change. Moreover, crisis not only shows otherwise hidden social/power dynamics, but can be understood as objectively overdetermined by more than one set of sufficient causes or conditions, yet subjectively indeterminate (Sum and Jessop 2013).

These various (mainly) disciplinary studies have contributed critical insights about the study of crisis. Yet there has not been a profound engagement with a structured interdisciplinary perspective that takes account of the complexity and interconnected nature of crisis. In the context of complexity, and what we now understand as the wicked problems of the day such as climate change, economic failures and growing socio-economic inequality, solutions must be built with an understanding of social complexity thus drawing on several and various disciplines. A wicked problem has been defined by Horst W.J. Rittel (1973) as one for which each attempt to create a solution changes the understanding of the problem. Wicked problems cannot be solved in a traditional linear and single discipline fashion, because the problem definition evolves as new possible solutions are considered and/or implemented. Studying and intervening in crises requires non-linear approaches which connect across disciplines to develop more comprehensive, interdisciplinary understandings of societal problems and better solutions (noting that there is never a correct solution to a wicked problem).

What these considerations point to is the need to develop more complex and multi-faceted views of crisis, not only in its particular instantiations but also as a cross-cutting concept and phenomenon. Examining the intricate and complex character of crises, their composition, intersections and responses not only requires multi- and cross-disciplinary approaches, there is also something to be gained from developing a genuinely interdisciplinary grammar for thinking and talking about crisis. This is a key ambition of this article: indeed, crisis studies seem almost naturally to lend themselves to interdisciplinary studies and analysis. Moreover, 
and fundamentally, we consider that the broad material impacts and harms of crisis and crises, in terms of violence, vulnerability, precariousness and risk, are so serious that there is a need to open up interdisciplinary spaces and perspectives to examine these questions, in short, to develop Interdisciplinary Crisis Studies.

\section{Empirical exemplars of Interdisciplinary Crisis Studies}

We now illustrate our approach by turning to two exemplars of crisis that may benefit from interdisciplinary analysis. We suggest that the use of broad and extended cases is particularly relevant in interdisciplinary crisis studies, rather than, say, isolated or short-term studies using only single methods such as qualitative interviews or questionnaires alone, to reflect the complexity of crises.

\section{Crisis and security}

Crisis and security are co-constitutive, with pressing global and domestic events and developments frequently being counched within the language of urgency and instability. Crisis, moreover, is employed within discourses and practices of hard (military, defence, terrorism) and soft (societal, environmental, economic and human) expression of security to alert audiences to escalating conflict, large scale events such as natural disasters or humanitarian rights abuse. Within orthodox security studies, associated with the realist branch of international relations scholarship, crisis tends to imply a state of emergency or an imminent threat to the nation's stability, national interests and survival (Waltz 1979). Since the end of the Cold War, however, scholars such as Lene Hansen (2012) and Barry Buzan et al. (1998), associated with the Copenhagen School (CS) of security studies, have critiqued the tendency, on the part of numerous actors to frame political, social and economic issues and dilemmas within speech acts pertaining to security, emergency and crisis (Hansen 2012; Buzan et al. 1998). Such securitising moves are often pursued by governments and international organisations to heighten the urgency of global events, and in the process reducing the significance of political, social and economic solutions to the issues at hand (Aggestam \& Bergman Rosamond 2019).

At the heart of the CS, however, there is a strong emphasis on the significance of avoiding moving issues out of the realm of normal politics, and into the area of extraordinary security politics, where notions of emergency and mobilization of security practices are the governing 
themes. Rather, governments and other actors should seek to desecuritise the issues in question by avoiding using security speech acts that might heighten the sense of urgency. By centring the analysis on states' responses to global events and security developments the CS tends to disregard individual human beings' everyday experiences of (in)security (Wibben 2011). What is more the CS is largely a western approach to security, not taking account of postcolonial insights and efforts to reduce the Eurocentricity that tends to surround notions of both crisis and security (Howell \& Richter-Montpetit 2019). Critical security studies (CSS), on the other hand, has adopted a normative approach to security, placing the security and emancipation of individual human beings at the centre of the analysis (Booth 2005). Yet, both the CS and CSS are broadly located within IR scholarship and, as such, do not fully engage with the insights on security harboured within the disciplines of law, environmental studies, anthropology, gender studies, political psychology and sociology to name a few. By coupling the CS and other critical perspectives on security (Wibben 2011) with the insights provided by non-IR perspectives new knowledge of the constitutive links between security and crisis logics can emerge, pertaining to the legal, psychological, gendered and historical underpinnings of any given crisis. The Copenhagen school, nonetheless, produces a fruitful starting point for thinking through ways in which crisis discourse and practice are securitised rather than politicised. The "War on Terror," global warming and melting sea ice in the Arctic (Bergman Rosamond 2011), famine and poverty in Africa and elsewhere, refugees and migration (Gammeltoft-Hansen 2016) as well as the widespread occurrence of sexual violence in conflict (Baaz-Eriksson and Stern 2013) are all examples of issues necessarily served by security politics, but rather require long-term structural responses involving legal, social and economic measures.

What is needed then is an active attempt to de-securitise (Hansen 2012) crisis , and as such move the issues in question away from the emergency zone to the political, legal and social realms. This is not dissimilar to the logic of politicisation of issues and events (Neal 2019; Mouffe 2018). For example, sexual violence in conflict is often packaged (and studied) as a security issue when what is needed is structural and legal transformative change of the global gender order that tends to privilege men's security at the expense of women's. As several scholars associated with feminist security studies (FSS) have pointed out, security studies often miss the gendered underpinnings of security and crises, domestically and globally (Hansen 2012; Hudson 2009). Unpacking these dynamics and providing more nuanced 
definitions and applications are thus significant when we conceptualise the co-constitutive relationship between crisis and security.

Our interdisciplinary framework for studying the connectedness between crisis and security, moreover, involves analysing a range of global and domestic policy issues and actors, across sectors and actors such as states, international organisations, civil society and local communities. Famine and poverty, economic hardship and environmental depletion are security issues that are ill-served by crisis logics. The \#MeToo campaign, as well as the global emphasis on sexual and gender-based violence in conflict, epitomise the intersections between crisis, law, trauma, gender, security and global politics more broadly, and how these are co-constitutive of various crises temporalities. In sum then, the frequent location of crisis within discourses and practices of securitisation needs to be investigated, but also challenged, taking account of multidisciplinary insights.

The study of the constitutive links between crisis and security also involves taking account of temporality with some crisis being near chronic (Rydstrom 2019a, 2019b, in press; Vigh 2008; Zhukova 2019) and others limited in time. For example, women living under the threat of violence, or who are subjected to abuse, might never be able to escape the shackles of local and global patriarchal power relations (Nguyen and Rydstrom 2018). Similarly, people living in disaster zones or refugee camps might experience a permanent sense of insecurity (Gammeltoft-Hansen 2016; Bergman Rosamond 2020). An interdisciplinary framework for studying crisis as a security dilemma needs to engage with these issues to understand the reciprocal relationship between crisis at a structural level and crisis and insecurities experienced on the ground(e.g. Samimian-Darash and Rotem 2018).

In taking account of the co-constitutive links between crisis and security, there are many avenues for important interdisciplinary empirical research with many insecurities being gendered. The \#MeToo campaign and gender-based violence are instructive examples in this context, and so is the tendency amongst some states and governments to heighten people's sense of risk and ontological insecurity, with the view of improving their crisis and war preparedness in response to shifts in the global security structure. In May 2018, Sweden distributed a pamphlet to 4.8 million households called Om krisen eller kriget kommer (If crisis or war comes). The pamphlet, developed by the Swedish Civil Contingencies Agency (MSB) advises citizens of how to prepare for a range of emergencies, such as a terrorist attack 
or an outage of communications and services. By creating notions of an emergent threat and emphasising resilience on the part of the general public a range of security and often crisisinfused measures can be justified (Youngs 2012). Our interdisciplinary framework seeks to provide unpack such constructions of emergency and crisis.

\section{Crisis and climate, conflict, migration and refugees}

Our second example of interdisciplinary analysis concerns the close alignment of crisis and climate change, conflict, migration and refugees. There is a variety of consequences to climate change impact, but few have received as much attention as human mobility- both from policy makers and media, and from the scientific community (Conisbee and Simms 2003; Renaud et al. 2007; Stern 2007; Warner et al. 2009, 2010).

The discourse on environmental displacement was originally dominated by four debates: labels and definitions (who or what is an environmental migrant), numbers (whether it is a measurable phenomenon), protection and assistance frameworks, and security threats to destination areas (Hamza et al. 2010; Hamza and Corendea 2012; Raleigh et al. 2008). The debated areas led to a degree of confusion among the general public, resulting also from misrepresentation in the media and the undeniable effect that populist movements had on such discourse, thus creating an atmosphere of apprehension and even hostility towards migrants/refugees combined with an inability to differentiate between a refugee and a migrant and stigmatizing both - the former fleeing a conflict and the latter could be forcibly displaced by deteriorating environmental conditions and loss of livelihoods (Bardsley and Hugo 2010; Gray and Bilsborrow 2013; Hamza and Corendea 2012; Piguet et al. 2011) .

In the case of crisis related to environmental and climate change displacement, migration drivers in human mobility processes in terms of causes and consequences are intricately linked to other forms of crises since human or societal systems do not operate in silos. In other words, migration, or indeed displacement, is not facilitated by a single factor but is an outcome of multiple socio-economic and political conditions including poverty, inequality, discrimination, weak governance, inadequate protection frameworks and lacking human security. ${ }^{7}$ Zetter and Morrissey (2014 a, b) thus demonstrate how displacement serves as a

\footnotetext{
7 This echoes Sen's (2012) notion that a famine has never happened in a democracy alluding to the role of governance in seemingly environmental crises.
} 
reflection, or a consequence, of a 'crisis of power,' since environmental factors cannot be disaggregated from the socio-political and economic processes that determine mobility decisions. In the five case studies this body of work is based on (Bangladesh, Ethiopia, Kenya, Vietnam and Ghana), what determines the pattern and regime of migration for the groups and individuals impacted by environmental stresses resulting from climate change is the exercise and articulation of 'material' versus 'structural' rights within systems of power in society, both historically (land ownership, use of communal resources, etc.) and in current politics (distribution of material rights, protection, etc.). In other words, migration and displacement is rooted in societal processes that may even predate any current environmental change or degradation, yet claims about current or future climate migration crises continue to be presented in entirely 'ahistorical' or 'apolitical' terms (Zetter 2010).

More fundamentally, the simplistic reduction of climate change as a cause of population movement facilitates apocalyptic and securitising narratives. Defining climate change and migration as security problems not only stigmatises migrants as demonstrated by the many captions and photographs published in digital and traditional media, it also serves to depoliticise climate governance (Bettini 2013). This in turn detracts from collective efforts to find policy alternatives and solutions that capitalize on the positive aspects of migration and push the discourse away from looking at the root causes of migration or indeed the underlying factors that climate change leverages (see also Buckingham and Masson 2017).

There is still a lack of protection frameworks, norms and instruments that link migration and displacement to rights concerns and/or ineffective application of existing instruments (Zetter and Morrissey 2014 b). The Human Security Framework has emerged as a viable approach, and further evidence for the need for a more interdisciplinary approach to complex crises by offering a broader view on environmentally induced migration. The United Nations University's Institute for Environment and Human Security and the Global Environmental Change and Human Security Project interact closely with the Intergovernmental Panel on Climate Change (IPCC 2018) and were behind the effected change in the Cancun text (Gomez 2013). A human security framework not only offers more flexibility in accommodating the non-linear multi-causal nature of environmentally-induced migration, it might also help tailor appropriate policy frameworks for those who migrate and those who stay behind rather than address the issue from a threat-to-security stance (Sylvester 2010). It is also a framework that 
requires an inter-disciplinary approach to understanding and articulating the migration and displacement crisis.

The European framing of response to what was referred to as a 'refugee crisis' in the public discursive domain since 2015 constitutes another point in case. Rising European asylum numbers and omnipresent media coverage was quickly labelled in language of crisis and security threat (Cabot 2018). Reflecting the breakdown of political trust, a number of Member States introduced internal border controls and other emergency measures (GammeltoftHansen and Tan 2016). Moreover, the so-called 'refugee crisis' was opportunely leveraged by both governments and national political parties to amplify a range of other agendas in regard to for example welfare crisis, national identity and anti-Europeanisation, the long-term consequences of which are still unfolding (Cabot 2018; Gammeltoft-Hansen 2016).

The 2015 European 'refugee crisis' holds important lessons for an interdisciplinary approach to crisis studies both in terms of how crises temporally unfold and who, crucially, gets to successfully claim and frame 'crisis.' Despite a significant drop in asylum numbers across the EU in both 2017 and 2018, it is noteworthy that emergency measures and national border controls have been continued in many Member States. Rather than EU-wide reforms, Member States are presently locked in the kind of 'race to the bottom'-policies that used to characterise Europe pre-harmonisation (Gammeltoft-Hansen 2017). The crisis in other words, takes on a life of its own, gradually shifting and mutating, and latching on to different agendas and issues.

From a sociology of science perspective, migration and refugee studies constitute what some scholars have labelled 'weak fields' (Vauchez 2008; cf Bourdieu et al. 1994); internally steered by a 'dual mandate' to simultaneously advance scholarship and refugee protection (Jacobsen and Landau 2008) and externally organised around various intersections with policy organisations and professional communities (Gammeltoft-Hansen and Byrne 2020). Within this field, claims to crisis are often related not only to humanitarian situations, but also to shifting policy agendas and scholarly arguments for more far-reaching political or legal reforms (Chimni 1998).

Following the events of 2015, several scholarly attempts have conversely been made to disclaim or counter public rhetoric around crisis (Collyer and King 2016; Crawley and 
Skleparis 2018; Allen et al. 2018), though for some scholars the 'refugee crisis' terminology has similarly been embraced in order to launch alternative reform proposals or rekindle political support (Betts and Collier 2018; Gammeltoft-Hansen 2016; Hathaway and Neve 1997). In addition, both the current and previous claims to 'refugee crisis' may be argued to have sparked several internal debates regarding scholarly positioning, involvement in policy processes and various forms of scholarly activism (Gammeltoft-Hansen and Byrne 2020).

More fundamentally, 'crisis' may impose structural changes in terms of a field's composition and positioning vis-à-vis both the wider academy and external stakeholders. There has been an undeniable surge in refugee research following the 2015 events. While refugee studies has traditionally been dominated by law, political philosophy and ethnographic approaches, many newcomers have come from other disciplines, in some cases openly challenging accepted wisdom or approaches within the dominant disciplines (Betts and Collier 2018; SamimianDarash and Rotem 2018).

Meanwhile, the perceived need for a political paradigm shift can make some policy-makers distrustful of existing scholarship, or label it as biased or politically normative. Within refugee studies, the legal discipline in particular has been at the vanguard of such struggles (Chimni 1998; Gammeltoft-Hansen and Byrne 2020). Thus former UN High Commissioner for Refugees, Sadako Ogata, is said to have openly proclaimed her disdain for refugee lawyers, whom she perceives as "rigid and backwards looking, invoking the past to frustrate the realistic and pragmatic approaches to refugee problems." (Goodwin-Gill 1996: 8). Struggles over the relative importance of academic expertise are thus something to be expected, not least in times where existing policy paradigms are failing and new ones being tested.

\section{Key features of Interdisciplinarity Crisis Studies}

Having set out the broad case for Interdisciplinary Crisis Studies, we now set out some key features of such an approach in more detail, beginning with temporality, spatiality and scale, before moving onto multi-layeredness, processuality and contradictions, and then to gender, intersectionality and social inequalities. As we note later, these features are not intended to be exhaustive, but more as heuristic guides to how interdisciplinary studies on crisis may be furthered. 


\section{Temporality, spatiality and scale}

In developing our interdisciplinary approach to and definition of crisis as a dynamic and fluid concept, temporality and spatiality are critical elements (Koselleck [1959] 1988; Roitman 2014). Time and space are keys both at a systemic and lifeworld level: in longer-term historical time, and in more immediate timespan in a global spatiality, and in a more immediate spatial sense. A crisis is shaped in context and by context in a particular time in a specific context meaning that a crisis is embedded in the progress of history and therefore cannot be static, though many people, might experience a sense of permanent crisis when finding themselves caught in zones which might be harmful, blur the horizon of potentiality and truncate agency. Thus, crisis is not to be reified or understood ahistorically. Accordingly, we see crisis as composed of tempo-spatial phases and intensities; a crisis might be a matter of emergency with which it is possible to cope and move forward; it might even lead to renewal (catharsis); or a crisis might settle as a new normalcy, as chronicity (Rydstrom 2019a, 2019b, in press; Vigh 2008; Zhukova 2019; Walby 2015). Crisis is uncertain and does not in itself predict a specific form of outcome.

The question of scale is significant to the understanding of crisis. In dealing with crisis, numerous scales may be involved from the level of the individual human body experiencing violence to the global level experiencing anthropogenic-induced climate change. Cross-scalar interactions occur in dealing with crisis and as Marston (2000) suggests scales become sites of social reproduction and consumption (Cash et al. 2006). Scalar configurations are thus an outcome of the perpetual flux of socio-spatial and environmental dynamics, and undergo transformations through social conflict and political-economic struggle (Hamza et al. 2010; Nguyen and Rydstrom 2018; Ramasar 2014). In dealing with crisis, scalar discourse sets the level at which a crisis is perceived to occur; institutional and jurisdictional scales set the boundaries of responsibility for action and biophysical conditions may determine who is directly affected by crisis. The relation between the discursive space of crisis and the material space of crisis management may be politically contested and affect our understanding of the scale of crisis.

Not unlike a narrative, a crisis commonly is seen as a demarcated event anchored in time and space with a beginning and an end regardless of whether the crisis is personal, political, economic or socio-cultural. As mentioned above, crisis tends to be understood as holding out a promise of positive change, but this might not always be the case. Yet, it is most often 
implied that the suffering encountered due to a crisis refers to a momentary phase, which will come to a closure (Gramsci 1971; Rydstrom 2019a, 2019b; Vigh 2008). More broadly, crises have historico-epistemological dimensions (Kuhn 1962), with it sometimes being formulated, as historically situated knowledge that in turn provides a shock to prevailing wisdom in economy, for instance, and dominant policy paradigms (Sum and Jessop 2013).

Giorgio Agamben $(1998,2005)$ has demonstrated that crisis in many instances of history and social life take proportions which go far beyond the idea of crisis as a brief interruption of the 'normalcy' of daily life. Conceptualizing crisis as an enduring condition in the camp, as analysed by Agamben (1998, 2005), or in a war zone, as examined by Henrik Vigh (2008), or in climate change impact as explored by Sara Bradshaw (2013) transforms the idea of crisis as a sudden incident into an overall encompassing impeding condition. This condition violates human rights and dignity by dehumanizing the other (Butler 2010; Rydstrom 2012). An enduring condition of crisis thus can morph into a new normalcy, into chronicity. This 'normalcy' interrupted by a sudden crisis due to conflict or climate disaster, for example, might not be crisis free in the first place, as clearly illustrated by intimate partner violence (Rydstrom 2017). A crisis interlocks with various crises antecedents with which people are already struggling and thus might augment already existing crisis conditions (Rydstrom 2019 in press). Climate change serves as one such pervasive crisis which interconnects multiple crises and serves to exacerbate the social, political, economic and environmental conditions of people globally and locally (Hamza et al. 2010; IPCC 2018).

In her discussion of crisis, Janet Roitman (2014) reasons that if crisis is conceptualized as a condition and experience detached from context, as chronicity, which then establishes as context, as Vigh (2008:8) suggests, crisis is no longer conceptualized as an event with a beginning and an end (see also Rydstrom 2019a, 2019b, in press). Rather, crisis is extending across time as a persistent condition and an overall encompassing experience, or as a norm, as Marx argues in his investigation of capitalism. If crisis is not signifying a turning point in terms of a historical change, crisis is freed "from its temporal confines" (Vigh 2008: 9). The decisive moments and critical conditions imbued in a crisis would in this perspective be rendered mundane, or banal in the words of Hannah Arendt (1970), and so would the pain, stress and disorder with which a crisis travels. Roitment (2014:66) thus argues that defining crisis as chronicity (Vigh 2008:9) disregards the temporality of crisis. If crisis is assumed to be a notion of temporality (Kocelleck 1988), Vigh's argument means that the notion is 
imploding upon itself. This, however, does not mean that time can have differentiated tempi and speed (see Rydstrom 2019a, 2019b, in press). Moreover, crises and their emergence are sometimes only clearer retrospectively, after actions that may at first not appear as crisisrelated, for example, in the relatively sudden and unpredicted occurrence of some financial crises; in that sense, crisis and crisis practices, individual or collective, are not necessarily performative.

Furthermore, crisis is both theoretically and ethnographically a decisive moment, a situation that has reached a critical phase which holds power to differentiate, select and separate both symbolically and literally. For instance, those affected by a conflict or a disaster resulting from a natural hazard as these do not have an indiscriminate effect. Moreover, it can be seen as "conditions that make outcomes unpredictable" (Habermas 1976: 1) and in this sense a "vitally important or decisive state of things" which evolves into a "point at which change must come, for better or worse".

\section{Multi-layeredness, processuality and contradictions}

The reciprocity between overall socio-economic and political structures and individual experiences of crisis on the ground indicates that crisis cannot be studied as a singular condition, but must be analysed in its multiplicity as layers of crises embedded in a sociocultural, political and economic landscape. A crisis then does not occur in a societal void but intersects with the difficulties already faced and the gender-specific and intersectional social inequalities in place. For some, a crisis is experienced as a temporary condition as a bracketing of the normality of daily life, which might even lead to renewal. For others, a crisis fortifies already existing crises conditions, for instance, due to poverty, displacement or conflict. When a crisis of an emergency such as a typhoon or an earthquake interlocks with encumbering socio-economic antecedents, the new crisis becomes an amplifier which capitalises upon, and even galvanize, existing inequalities many of which pertain to intersectional variation (Rydstrom 2019a, 2019b, in press).

Crisis can be understood as a condition which simultaneously, and contradictorily, incorporates the forces of ruination and renewal as a critical state which eventually would propel off or alternatively persist for a period of time (Nguyen 2019; Rydstrom and Kinnvall 2019; Stoler 2013; Walby 2015). Each crisis has its own composition and rhythm; a crisis can be momentary, it can pass quickly, or it can establish itself as a perpetual condition. However, 
through the interaction of crises and due to human capabilities (Nussbaum 2000), any type of crisis is saturated by dynamics. We would thus argue that crisis takes shape as a processual and perpetually transforming phenomenon, experience and political construction, and is thus both dynamic and fluid in nature. Even when appearing as chronic and when hampering agency, there is resilience, resistance, agency and hope for a life which is not defined by the difficulties of a crisis of the present (see Vigh 2008).

Thus, crises lead to multiple impacts, effects, potentials and contradictions, ranging from the creation of (neo liberal market) opportunities, to greater possibilities for collective agency for transformative change during and after crisis. On the first count, crisis can be an opportunity, for some at least, as when the material conditions of people are used to generate a discourse of crisis and create market opportunities, often in post-conflict or disaster settings (Brundiers 2016; Renner and Chafe 2007). For example, Naomi Klein (2007), in Shock Doctrine and elsewhere, has delved in this respect into the murky waters of disaster capitalism. The cases of health crises and the role of big pharma are instructive here. Thus, the crises which cause the greatest loss Disability-Adjusted Life Years (DALYs) are not the ones that benefit from significant research or drug therapies, whilst non-communicable diseases receive attention through medical relief rather than proactive health maintenance. Additionally, pandemic narratives have created spaces for securitization and the restriction of the mobility of people (Guild 2009; Huysmans 2000). Similarly, the crisis of climate change and ecological disaster has given rise to carbon markets and green capitalism as a response from within the current system (NG Anderson 2018).

Meanwhile, the discursive space created by a larger societal crisis can also be an opportunity for transformative change through the creation of collective agency and dialogue. Drawing on the ideas of Karl Polanyi, crisis can be seen as a moment for great transformation. In response to crisis and for example the creation of neoliberal markets, a societal pushback can develop through society's double movement.

Indeed, in situations of crisis where the status quo is untenable, crisis can create the opportunity for collective agency producing social revolution as the end of the Cold War revealed. Another example is the social mobilization for environmental justice within or following crisis (Kinnvall and Rydstrom 2019). Another, rather different example concerns the collective actions by widows of men who died from AIDS-related diseases in Onjiko 
region in Kenya to support each other in livelihood strategies (Gabrielsson and Ramasar 2013). Because they were stigmatized, they came together and were able to work outside the norms or the local community and introduce innovative measures in the agricultural sector which resulted in the establishment of a collective women's farming group, and ultimately, food security for the women and their families.

\section{Gender, intersectionality and social inequalities}

A crisis is the result of complex social relations and social dynamics ignited by individuals, groups, states, political parties, finances, cultures and the sphere called 'nature', which are encroaching with differentiated ramifications upon societies and people due to their gender, sexuality, ethnicity, age, ablebodiedness, and class (Rydstrom 2019, in press, in press). The rapid societal shifts provoked by a crisis thus tend to have multiple implications for social inequalities and social divisions, such as class, race, gender and their intersections. These in turn have multiple implications for power relations, experiences of violence and subordination, multiple voices, interpretations, priorities, and management and policy development in connection with particular crises (Buckingham and Masson 2017; Enarson and Pease 2016; Hearn 2015; Walby 2015).

More specifically, crisis is inherently gendered, or rather intersectional and intersected, in the sense that gender is consolidated in particular sites through intersections with other defining resources and parameters, as discussed by Kimberlé Crenshaw (1991). Gender engages with age, sexuality, ethnicity/race, class, and ablebodiedness (amongst other parameters) to produce images and realities of people, their powers, roles, status, and abilities. According to Nancy Fraser (1996: 16), gender "codes pervasive cultural patterns of interpretation and evaluation, which are central to the status order as a whole". Such patterns shape and are shaped by androcentrism; a forceful power, which Fraser (1996: 16) has defined as "the authoritative construction of norms that privilege traits associated with masculinity and the pervasive devaluation and disparagement of things coded as 'feminine', paradigmatically but not only - women”. Indeed, crises may often be generated or underpinned by societal conditions, institutions and situations dominated by certain men and masculinities (Hearn et al. 2019).

In identifying how societal antecedents frame and restrict gendered and intersected life, it is clear that a crisis does not emerge in a socio-economic and political void but in places where 
the autonomy and rights of women and girls might be sorely limited. Crisis due to war or climate disasters is intimately intertwined with gender-specific inequalities that defined ordinary times. These might in times of new types of crises be fuelled or even exacerbated thus making women and girls particularly susceptible to short-term and long-term crisis precariousness (Godfrey and Torres 2016; Nguyen and Rydstrom 2018; Rydstrom and Kinnvall 2019).

Gendering, intersectional gendering, of crises is thus not to be reduced only to impacts on women; gendering, intersectional gendering, of crises also concerns both the gendered creation (production) and maintenance (reproduction) of crises, and the institutional and noninstitutional responses to crises. The construction, production and reproduction of crises are thus intersectionally gendered in ongoing processes.

\section{Conclusions: an interdisciplinary framework for the study of crisis}

Crisis, and talk of crisis, appear to be everywhere, on everyone's lips: economic crisis, fiscal crisis, climate crisis, political crisis, migration crisis, policy crisis, gender crisis, even existential crisis. The word and the concept of 'crisis' may seem over-used, whether in everyday, policy, political or academic discourse, even while there are clearly major and dire crises of various kinds across the world. It is these kinds of crises that we have been most concerned with.

It may be unusual for a crisis to occur in isolation. More usually, crises interconnect with each other, with one crisis leading onto another crisis, in what may be thought of chains of crises. In some cases, crises overlap, for example, between environmental, political and economic crises, or are even coterminous with each other; more usually crises lead onto other crises, sometimes exacerbating other crises, and sometimes ameliorating other crises. Furthermore, these chains of crises and inter-crisic relations necessarily have a temporal and spatial dimensions, with the political rhetoric of some crises in one place, for example, around a "migration crisis", following the height of dire, material crises of war and initial displacement elsewhere.

In this article, we have sought to outline some of the key features of what we see as emerging Interdisciplinary Crisis Studies. First and obviously, we have highlighted throughout the need to move from purely disciplinary approaches towards the central theme of interdisciplinarity. 
In addition, questions of temporality, spatiality and scale, of multi-layeredness, processuality and contradictions, and gender, intersectionality and social inequalities have been identified. A further feature that is apparent from the two exemplars is how different kinds of crisis, for example, around security, climate change or migration, overlap and intersect with each other, and act as precursors or consequences of other crises, in what can be thought of inter-crisic relations or chains of crises. In these argumentations, we seek to both de-essentialise the notion of crisis as historical, contingent and uncertain, but also to consider some recurring features of crises that cut across specific disciplinary frames. As such, we define crisis as an interdisciplinary object of study, and intervention, and simultaneously deconstruct 'crisis'. As we have argued, crisis is volatile both in its theoretical conceputalization and as an emprical event. The analytical strength of crisis as a notion lies in its ability to capture the temporality, modality, and intensity of a specific crisis as it is playing out in a particular context and framing life differently along the lines of gender, age, class, ethnicity, sexuality, and bodyableness. While much research on crisis tends to define crisis as an event, which undergoes a number of predictable phases including interruption, struggle, and renewal, we have in this article demonstrated how crisis is a notion that gains substance through its dialectical relation to the empirical condition it seeks to critically explore. Not unlike the Foucauldian (1978) notion of power, the concept of crisis is defined by elusiveness and the ways in which it accrues meaning through the interdisciplinary analysis of an empirical event; a rupture, or crisis shaped in time and space (see Rydstrom 2019a, 2019b, in press).

Finally, as shown by Thomas Kuhn (1962), crisis is a critical part of scholarly knowledge production. As such, crisis may arise internally, for example, as part of methodological or theoretical struggles currently sweeping several disciplines within the natural sciences. But for fields and disciplines organised around social phenomena and problem-solving research, political claims to crisis may have equally far-reaching consequences. In this spirit, while we have argued here for the centrality of interdisciplinarity in studying crisis, we do not see this as a fixed and final position, but rather one that is itself subject to further challenge and development. Specifically, this may entail the movement from the aggregation of disciplines within multi-disciplinarity to inter-disciplinarity, and then towards trans-disciplinarity, and even post-disciplinarity. To be clear, this last possible position is not to argue for the supersession of disciplines, nor for the specific epistemologies of the 'post' (as is postmodernism, for example), but rather that the drastic nature of crises may demand drastic collective academic interdisciplinary, trans-disciplinary and post-disciplinary ways forward. 


\section{References}

Agamben, G. (1998) Homo Sacer: Sovereign Power and Bare Life. Stanford: Stanford University Press.

Agamben, G. (2005) State of Exception. Chicago: The University of Chicago Press.

Aggestam, K. and Bergman Rosamond, A. (2019) 'Re-politicising the Gender-Security Nexus: Sweden's Feminist Foreign Policy', European Review of International Studies, 4 (3): $30-48$.

Allen, W., Anderson, B., Van Hear, N., Sumption, M., Düvell, F., Hough, J., Rose, L., Humphris, R. and Walker, S. (2018) 'Who Counts in Crises? The New Geopolitics of International Migration and Refugee Governance', Geopolitics, 23(1): 217-243.

Andersson, F. NG. (2018) 'International Trade and Carbon Emissions: The Role of Chinese Institutional and Policy Reforms', Journal of Environmental Management, 204(1): 29-39.

Arendt, H. (1970) On Violence. New York: Harcourt Brace and Company.

Ba, H. (2017) 'The Systemic Causes of Financial Crises in the Long Nineteenth Century', Business and Politics, https://doi.org/10.1017/bap.2017.22 14 September.

Baaz-Eriksson, M. and Stern, M. (2013) Sexual Violence as a Weapon of War? Perceptions, Prescriptions, Problems in the Congo and Beyond. London: Zed Books.

Bardsley, D.K. and Hugo, G.J. (2010) 'Migration and climate change: examining thresholds of change to guide effective adaptation decision-making', Population and Environment, 32 (2-3): 238-262.

Berckmoes, L. (2017) 'Reproducing Ambiguities in Enduring and Looming Crisis in Burundi', Ethnos: Journal of Anthropology, 82(5): 925-945.

Bergman Rosamond, A. (2011) Perspectives on security in the Arctic area : DIIS report, Copenhagen: Danish Institute for International Studies.

Bergman Rosamond, A. (2020) 'Celebrity global motherhood: Maternal care and cosmopolitan obligation', in Shepherd, L., Hall, L. and Weissman, A (eds) Troubling Motherhood: Interrogations of Maternity in Global Politics, Oxford: Oxford University Press.

Berman, M. (1982) All That Is Solid Melts Into Air: The Experience of Modernity, New York: Simon and Schuster.

Bettini, G. (2013) 'Climate Barbarians at the Gate? A critique of apocalyptic narratives on climate refugees', Geoforum 45: 63-72.

Betts, A. and Collier, P. (2018) Refuge: Transforming a broken refugee system, London: Penguin.

Booth, K., (2005) Critical Security Studies and World Politics, London: Lynne Rienner.

Bourdieu, P., Waquant, L. and Farage, S. (1994) 'Rethinking the State: Genesis and Structure of the Bureaucratic Field', Sociological Theory, 12(1): 2-18.

Bradshaw, S. (2013) Gender, Development and Disasters, Cheltenham and Northampton: Edward Elgar. 
Brundiers, K. (2016) Disasters as Opportunities for Change Towards Sustainability, Arizona State University Doctoral Thesis.

Buckingham, S. and Masson, V. (2017) Understanding Climate Change Through Gender Relations, London and NY: Routledge.

Butler, J. (2010) Frames of War: When is Life Grievable? London: Verso.

Buzan, B. Weaver, O. and De Wilde, J. (1998) Security: A New Framework for Analysis, Boulder, CO Lynne Rienner Publishers.

Cabot, H. (2018) 'The European Refuge Crisis and Humanitarian Citizenship in Greece', Ethnos, Journal of Anthropology, 84(5): 747-771.

Carchedi, G. and Roberts, M. (2018) World in Crisis: Marxist Perspectives on Crash and Crisis, Washington DC: Zero.

Cash, D.W., Adger, W.N., Berkes, F., Garden, P., Lebel, L., Olsson, P., Pritchard, L., and Young, O. (2006) 'Scale and Cross-Scale Dynamics: Governance and Information in a Multilevel World', Ecology and Society, 11(2): 8-20.

Chimni, B. S. (1998) 'The Geopolitics of Refugee Studies and the Practice of International Institutions: A View from the South', Journal of Refugee Studies, 11(4): 350-374.

Cohen, S., Gianaros, P.J., and Manuck, S. B. (2016) 'A Stage Model of Stress and Disease', Perspectives in Psychological Science, 11(4): 456-463.

Collyer, M. and King, R. (2016) 'Narrating Europe's migration and refugee 'crisis', Human Geography, 9(2): 1-12

Conisbee, M. and Simms, A. (2003) Environmental Refugees: The Case for Recognition, New Economics Foundation: London.

Connell, R. (1987) Gender and Power: Society, the Person and Sexual Politics, Cambridge: Polity.

Crawley, H. and Skleparis, D. (2018) 'Refugees, migrants, neither, both: categorical fetishism and the politics of bounding in Europe's 'migration crisis', Journal of Ethnic and Migration Studies, 44(1): 48-64.

Crenshaw, K. (1989) 'Demarginalizing the Intersection of Race and Sex: A Black Feminist Critique of Antidiscrimination Doctrine, Feminist Theory and Antiracist Politics', University of Chicago Legal Forum, issue 1, article 8.

Crutzen, P. J. (2006) The “Anthropocene”. In Ehlers E., Krafft T. (eds), Earth System Science in the Anthropocene, Berlin: Springer, 13-18.

Dewey, J. (1997) How We Think, Mineola, NY: Dover Publications

Diamond, J. (2005) Collapse: How Societies Choose to Fail or Survive, London: Penguin.

Diamond, J. (2019) Upheaval: How Nations Cope with Crisis and Change, London: Allen Lane.

Enarson, E. andPease, B. (2016) Men Masculinities and Disaster, London: Routledge.

Ferguson, N. (2012) The Great Degeneration: How Institutions Decay and Economies Die, London: Penguin.

Foucault, M. (1978). The History of Sexuality. Vol. 1. Harmondsworth: Penguin Books.

Fraser, N. (2001) 'Rethinking Recognition', New Left Review, 3(May-June). 
Fukuyama, F. (2011) The Origins of Political Order: From Prehuman Times to the French Revolution, New York: Farrar, Straus and Giroux.

Fukuyama, F. (2014) Political Order and Political Decay: From the Industrial Revolution to the Present Day, New York: Farrar, Straus and Giroux.

Gabrielsson, S. and Ramasar, V. (2013) 'Widows: Agents of change in a climate of uncertainty', Journal of Cleaner Production, 60(1), 34-42.

Gammeltoft-Hansen, T. (2016) 'Hvordan løser vi flygtningekrisen?' Copenhagen, Information Forlag.

Gammeltoft-Hansen, T. and Byrne, R. (2020) 'International refugee law between scholarship and practice', International Journal of Refugee Law.

Gammeltoft-Hansen, T. and Tan, N. F. (2016) 'The End of the Deterrence Paradigm? Future Directions for Global Refugee Policy,' Journal of Migration and Human Security 5(1), 28-56.

Gammeltoft-Hansen, T. (2017) 'Refugee Policy as 'negative nation branding': the case of Denmark and the Nordics', Copenhagen/DIIS: Danish Foreign Policy Yearbook.

Godfrey, P. and Torres, D. (2016) Systemic Crises of Global Climate Change: Intersections of Race, Class and Gender. London and NY: Routledge.

Gomez, O. (2013) 'Climate change and migration: A review of the literature', Working Paper No. 572 (International Institute of Social Studies (ISS)).

Goodwin-Gill, G. (1996) Refugee Identity and the Fading Prospects of International Protection. Conference on Refugee Rights and Realities. Human Rights Law Centre, University of Nottingham. 30 November 1996.

Gramsci, A. (1971) Selections from the Prison Notebooks, "Wave of Materialism” and "Crisis of Authority”, NY: International Publishers.

Gray, C. and Bilsborrow, R. (2013) 'Environmental Influences on Human Migration in Rural Ecuador', Demography, 50(4): 1217-41

Griffin, D. R. (2015) Unpredecented: Can Civilization Survive the CO2 Crisis?, Atlanta: Clarity Press.

Guild, E. (2009) Security and Migration in the 21st Century, Cambridge: Polity Press.

Habermas, J. (1976, 1992) Legitimation Crisis, Cambridge: Polity.

Hamza, M. (ed.) (2015) World Disasters Report: Local Actors the Key to Humanitarian Effectiveness, Geneva: International Federation of the Red Cross and Red Crescent Society (IFRC).

Hamza, M. and Corendea, C. (eds.) (2012) Climate Change and Fragile States: Rethinking Adaptation, United Nations University and Munich-Re Foundation, SOURCE No. $16 / 2012$.

Hamza, M., Morinière, L., Taylor, R., Matin, N., andAli, B. (2010) 'Emerging Issues: Forced Migration by Climate Change', in Fujikura, R. and Kawanishi, M. (eds.) Climate Change Adaptation and International Development: Making Development Cooperation More Effective, JICA Research Institute, Earthscan, 333-362. 
Hansen, L. (2012) 'Reconstructing desecuritisation: the normative-political in the Copenhagen School and directions for how to apply it', Review of International Studies, 38:3: 525-546.

Hathaway, J. and Neve, A. (1997) 'Making international refugee law relevant again: A proposal for collectivized and solution-oriented protection', Harvard Human Rights Journal, 10, 115-212.

Hearn, J. (1982) 'Decrementalism: the practice of cuts and the theory of planning', in Healey, P., McDougall, G. and Thomas, M. (eds.) Planning Theory in the 80s, Oxford: Pergamon, 161-179.

Hearn, J. (1998) The Violences of Men, London: Sage

Hearn, J. (2015) Men of the World: Genders, Globalizations, Transnational Times. London: Sage.

Hearn, J. and Roberts, I. (1976) 'Planning under difficulties: the move to decrementalism', in Jones, K. (ed.) The Yearbook of Social Policy in Britain 1975, Routledge and Kegan Paul, London, 3-18.

Hearn, J., Hughson, M. and Vasquez del Aguila, E. (2019) 'Introduction: Unsustainable institutions of men: transnational dispersed centres and immanent contradictions', in Hearn, J., Vasquez del Aguila, E. and Hughson, M. (eds.) Unsustainable Institutions of Men: Transnational Dispersed Centres, Gender Power, Contradictions, London: Routledge, 1-21.

Howell, A., \& Richter-Montpetit, M. (2019) 'Is securitization theory racist Civilizationism, methodological whiteness, and antiblack thought in the Copenhagen School' Security Dialogue, Online First, p. 1-20.

Hudson, N. F. (2009) 'Securitizing Women's Human Rights', Journal of Human Rights, 8(1): 53-70.

Huysmans, J. (2000) 'The European Union and the Securitization of Migration', Journal of Common Market Studies, 38(5): 751-777.

IPCC (2018) Special Report: Global Warming of $1.5^{\circ}$ C. Intergovernmental Panel on Climate Change. https://www.ipcc.ch/sr15/

Jacobsen, K. and Landau, L. (2008) 'The Dual Imperative in Refugee Research: Some Methodological and Ethical considerations in Social Science Research on Forced Migration', Disasters 27(3), 185-206

Jaques, T. (2009) 'Issue Management as a Post-Crisis Discipline: Identifying and Responding to Issue Impacts beyond the Crisis', Journal of Public Affairs, 9(1): 35-44.

Judis, J. (2016) 'How the Great Recession Transformed American and European Politics', Columbia Global Reports, New York: Columbia.

Kierkegaard, S. (1847) Kjerlighedens Gjerninger. Copenhagen: Saxo.

Kinnvall, C. and Rydstrom, H. (eds) (2019) Climate Hazards, Disasters, and Gender Ramifications, London and New York: Routledge.

Klein, N. (2007) Shock Doctrine, Toronto: Random House of Canada.

Koselleck, R. (1959, 1998) Critique and Crisis: Enlightenment and the Pathogenesis of Modern Society, Cambridge, MA: MIT Press.

Kuhn, T. S. (1962) The structure of scientific revolutions, Chicago, University of Chicago Press. 
Latour, B. (1993) We Have Never Been Modern, Cambridge, MA: Harvard University Press.

Marston S. (2000) 'The social construction of scale' Progress in Human Geography 24: 21942.

Marx, K. and Engels, F. (1848/2010) 'The Communist Manifesto', Collected Works of Karl Marx and Frederick Engels, 6: 477-506. Digital Edition: Lawrence and Wishart.

Mouffe, C. (2018) For a Left Populism, London: Verso.

Neal, A. (2019) 'Parliamentary Security Politics as Politicisation by Volume', European Review of International Studies, 5(3):70-93.

Nguyen. H. (2019). 'In the Wake of Haiyan', in Kinnvall, C. and H. Rydstrom (eds), Climate Hazards, Disasters and Gender Ramifications, London and New York: Routledge, 230248.

Nguyen, H.T. and Rydstrom, H. (2018) 'Climate Disaster, Gender, and Violence: Men's Infliction of Harm upon Women in the Philippines and Vietnam', Women's Studies International Forum, 71: 56-62.

Nussbaum, M. (2000) Women's Capabilities and Social Justice. Journal of Human Development, 1(2): 219-247.

Piguet, E., Pécoud, A. and de Guchteneire, P. (2011) Migration and Climate Change: An Overview, Refugee Survey Quarterly, 30(3), 1-23.

Polanyi, K. (1944) The Great Transformation, New York: Farrar and Rinehart.

Raleigh, C., Jordan, L. and Salehyan, I. (2008) 'Assessing the impact of climate change on migration and conflict', World Bank Seminar on Exploring the Social Dimensions of Climate Change Washington DC: The World Bank.

Ramasar, V. (2014) Fluid governance: Scalar politics in the South African waterscape. Lund: Lund University.

Renaud, F., Bogardi, J., Dun, O. and Warner, K. (2007) 'Control, Adapt or Flee: How to face environmental migration?' InterSecTions (5), Bonn: United Nations University Institute for Environment and Human Security.

Renner, M. and Chafe, Z. (2007) 'Beyond Disasters: Creating Opportunities for Peace', Worldwatch Report 173.

Repko, F.R; Szostak, R. and Philips Buckberger, M. (2014) Introduction to Interdisciplinary Studies, London: Sage.

Rittel, H.W.J. and Webber, M.M. (1973) 'Dilemmas in a general theory of planning'. Policy sciences. 4(2):155-169

Roitman, J. (2014) Anti-Crisis, Durham: Duke University Press.

Rydstrom, H. (2012) 'Gendered Corporeality and Bare Lives', Signs, 37(2): 275-301.

Rydstrom, H. (2017) 'A Zone of Exception: Gendered Violences of Family 'Happiness' in Vietnam', Gender, Place and Culture, 24(7): 1051-1070.

Rydstrom, H. (2019a) 'Disasters, Ruins, and Crises: Masculinity and Ramifications of Storms in Vietnam', Ethnos, Journal of Anthropology, published online before print. https://doi.org/10.1080/00141844.2018.1561490

Rydstrom, H. (2019b) 'Crises, Ruination and Slow Harm: Masculinized Livelihoods and Gendered Ramifications of Storms in Vietnam', In Kinnvall, C. and Rydstrom, H. (eds), 
Climate Hazards, Disasters, and Gender Ramifications, London and New York: Routledge 213-229.

Rydstrom, H. (in press) 'Machinery of Male Violence: Embodied Properties and Chronic Crisis amongst Partners in Vietnam'. Asia Pacific Journal of Anthropology, Austrian Journal of South-East Asian Studies, 12(2).

Rydstrom, H. and Kinnvall, C. (2019) 'Introduction: Climate Hazards, Disasters and Gender Ramifications', In Kinnvall, C. and Rydstrom, H. (eds), Climate Hazards, Disasters, and Gender Ramifications, London and New York: Routledge 1-25.

Said, E. (1979) Orientalism. New York: Vintage Books.

Samimian-Darash, L. and N. Rotem (2018) 'From Crisis to Emergency: The Shifting Logic of Preparedness', Ethnos, Journal of Anthropology, https://doi.org/10.1080/00141844.2018.1551239

Shiva, V. (1991) Staying Alive: Women, Ecology and Survival in India, London: Zed Books.

Smith, D. and Vivekananda, J. (2009) Climate Change, Conflict and Fragility: Understanding the Linkages, Shaping Effective Responses, The Initiative for Peacebuilding.

Starck, K. and Luyt, R. (2018) 'Political Masculinities, Crisis Tendencies, and Social Transition: Toward an Understanding of Change', Men and Masculinities, online first.

Stern, N. (2007) The Economics of Climate Change: The Stern Review, Cambridge University Press, Cambridge.

Stoler, A. (2013) Imperial Debris: On Ruins and Ruination, Durham: Duke University Press.

Sum, N.L. and Jessop, B. (2013) Towards a Cultural Political Economy: Putting Culture in its Place in Political Economy, Cheltenham: Edward Elgar.

Sylvester, C. (2010) 'Tensions in Feminist Security Studies,' Security Dialogue, 41:607.

True, J. (2012) The Political Economy of Violence against Women, Oxford: University of Oxford Press.

True, J. (2013) 'Gendered Violence in Natural Disasters: Learning from New Orleans, Haiti and Christchurch', Aotearoa New Zealand Social Work, 25(2):78-89.

Vauchez, A. (2008) 'The Force of a Weak Field: Law and Lawyers in the Government of the European Union (For a Renewed Research Agenda)', International Political Sociology 2(2): $128-144$

Vigh, H. (2008) 'Crisis and Chronicity: Anthropological Perspectives on Continuous Conflict and Decline', Ethnos, Journal of Anthropology, 73(1): 5-24.

Walby, S. (2015) Crisis, Oxford: Polity.

Waltz, K. (1979) Theory of International Politics, Massachusetts: Addison-Wesley.

Warner, K., Ehrhart, C., de Sherbinin, A., Adamo, S. and Chai-Onn, T. (2009) In Search of Shelter: Mapping the Effects of Climate Change on Human Migration and Displacement Institute for Environment and Human Security, United Nations University, CARE International, Center for International Earth Science Information Network, United Nations High Commission for Refugees, and The World Bank.

Warner, K., Hamza, M., Oliver-Smith, A., Renaud, F. and Julca, A. (2010) 'Climate Change, Environmental Degradation and Migration', Natural Hazards, 55(3): 689-715. 
Wibben, A., (2011) Feminist Security Studies- A Narrative Approach, London: Routledge.

Wester, M.; Sildemark, B. and Bülow, W. (2011) Assessing public acceptance of privacyinvasive ICT solutions, Stockholm, Myndigheten för samhällsskydd och beredskap (MSB).

Youngs, G. (2012) 'Feminist International Relations and Intelligence in a High Tech Age', In Bergman Rosamond, A. and Phythian, M. (eds). War, Ethics and Justice: New Perspectives on a Post-9/11 World, London: Routledge.

Zetter (2010) 'Reframing Displacement Crises as Development Opportunities'. Policy Brief prepared for the Global Initiative on Solutions, Copenhagen Roundtable, 2-3 April 2014.

Zetter and Morrissey (2014a) 'The Environment-Mobility Nexus: Reconceptualising the Links between Environmental Stress, (Im)mobility, and Power [Chapter 27, pps 342-354, in: Fiddian-Qasmiyeh, E., Loescher, G., Long, C. and Sigona, N. (eds), Oxford Handbook of Refugee and Forced Migration Studies. Oxford University Press, UK.

Zetter and Morrissey (2014b) 'Environmental Displacement and the Challenge of Rights Protection'. Forced Migration Review 45, February 2014, pp 67-71.

Zhukova, E. (2019) 'Nuclear disaster as chronic crisis: Accounts of radiation embodiment by survivors of the Chernobyl nuclear disaster from Belarus born before, in and after 1986', Health, 13: 1363459319829190

\section{Acknowledgments}

This article is one of several results of a series of initiatives focused on critical explorations of crisis including a Grace and Philip Sandblom Foundation funded symposium on crisis at Lund University; a Pufendorf Institute funded Advanced Study Group, which allowed for a series of symposia on crisis at Lund University; and a Pufendorf Institute funded Crisis Theme, which ensured that time could be reserved to examine crisis and the organization of a larger symposium also held at Lund University. The crisis study initiative has been coordinated by Helle Rydstrom and includes all authors of this paper and the financial support it has received is greatly appreciated. Thanks to the funding, we have been able to engage in the demarcation of the field of interdisciplinary crisis studies and launch the Society for Critical Studies of Crisis (SCSC). We are grateful for the helpful referee comments offered on an earlier version of the article, and for kind editorial support.

2 https://www.etymonline.com/word/crisis

3 https://www.merriam-webster.com/dictionary/crisis 